DOI:

Тетяна Гарбуза, кандидат педагогічних наук, доиент кафедри сучасних європейських мов Київського національного торговельно-економічного університету

\title{
ЗАСТОСУВАННЯ МОДЕЛІ ВLENDED LEARNING ПІД ЧАС ВИКЛАДАННЯ КУРСУ “ІНОЗЕМНА МОВА ЗА ПРОФЕСІЙНИМ СПРЯМУВАННЯМ"
}

У статті розглядається освітня концепція, змімане навчання, яка поєднує в собі всі характеристики інформаційних освітніх технологій. На сьогодні серед учених немає єдиного погляду на зміст изого явища. На підставі аналізу наукової літератури автором проаналізований зміст та ознаки поняття “змімане навчання”, здійснена та узагальнена класифікація його моделей. Зазначено, щзо використання змішаного навчання у вищчій освіті розв 'язує проблеми індивідуалізаџії, інтенсифікації та оптимізації навчання, є найбільщ логічною та природною еволючією традиційної моделі навчання.

Ключові слова: технологія; інформаційно-комунікативні технології; змішане навчання; моделі; іноземна мова; вища освіта.

תim. 6.

Tetyana Harbuza, Ph.D.(Pedagogy), Associate Professor of the Modern European Languages Department Kyiv National University of Trade and Economics

\section{INTRODUCING THE BLENDED LEARNING MODEL FOR TEACHING THE COURSE "FOREIGN LANGUAGE FOR PROFESSIONAL PURPOSES"}

In Ukraine teaching students the course "Foreign Language for Professional Purposes" is considered to be the priority of higher education. The ability to communicate in other languages plays a vital role in professional competence of specialists. With changing requirements to specialist's training there is a need to change the approaches of teaching the Foreign Language for Professional Purposes to students of different specialties. The relevance of the material presented in the article is caused by the system implementation of modern information and communication technologies into the educational process of higher educational institutions that induces the appearance of new kinds and forms of its organization. The formation of competences in the field of multimedia, which is necessary for the use of Internet technologies, plays an important role in this process. It ensures the preparation of highly qualified and highly competitive professionals. The article considers the peculiarities of using the information educational technologies while teaching English to non-language students. Blended learning is suggested to be used as it combines all the characteristics of information and educational technologies. Moreover, the article reveals the potential of blended learning as a means of increasing efficiency of education. Today, there is no single view of the content of this phenomenon among scientists. Based on the analysis of scientific literature and practical developments of pedagogical community the author has analyzed the content and features of the concept "blended learning". The classification of blended learning models is presented and generalized. It is stated in the article that the use of blended learning in higher education solves the problem of individuation, intensification and optimization training, is the most logical and natural evolution of the traditional model of learning.

Keywords: technology; informational and communicational technologies; blended learning; models; the foreign language; higher education.

П остановка проблеми. Сучасному суспільству потрібні фахівці, що володіють гнучкістю й адаптивністю, здатні переробляти значні обсяги інформації, отримувати та оновлювати знання, постійно вдосконалювати професійні компетенції. Але чинна система традиційного навчання не дозволяє в повній мірі реалізувати такі запити суспільства. Технологія Blended Learning, або змішане навчання, що поєднує сильні сторони традиційного навчання і переваги дистанційних технологій, $є$ дієвим способом вирішення відповідної проблеми.

Сьогодні Blended Learning називають освітою третього покоління. Перше покоління - під час аудиторних занять викладач використовував радіо і телевізійні передачі в режимі прямої трансляції. Друге покоління - це застосування простих інформаційних технологій: навчання за допомогою комп'ютерів та використання елементарних Інтернет-технологій. Третє покоління - це навчання в аудиторіях, під час яких використовуються різні інформаційні технології для виконання самостійної роботи студентами.

Аналіз останніх досліджень і публікацій. Питання щодо організації навчання на відстані розглядається в наукових працях: А.А. Андрреєва, 


\section{ЗАСТОСУВАННЯ МОДЕЛ ВLENDED LEARNING ПІД ЧАС ВИКЛАДАННЯ КУРСУ "ІНОЗЕМНАМОВАЗА ПРОФЕСІЙНИМ СПРЯМУВАННЯМ"}

І.В. Бацуровської, В.Ю. Бикова, Ю.М. Богачкова, Н.О. Корсунської, В.М. Кухаренка, Н.В. Морзе, Е.С. Полата, Б.І. Шуневича, Л.С. Петухової, О.В. Співаковського, М.С. Львова та ін.

Використання освітньої моделі Blended Learning в процесі вивчення окремих курсів висвітлюють О.М. Спірін, Ю.В. Триус, С.В.Желнова, М.С. Нікітіна, В.М. Кухаренко, А.М. Стрюк, Н.В. Рашевська та ін., які наводять різні визначення поняття “змішане навчання” та дають власне його тулмачення, визначають його переваги, недоліки та особливості, описують моделі змішаного навчання тощо.

Д. Соерс і Р. Уокер заначають, що студенти, до яких застосовувалося змішане навчання, вказали, що така система організації курсу корисніша, ніж традиційне аудиторне зайняття. Багато вчених відмічають позитивні риси й важливість електронного навчання. Серед них А.Є. Сатуніна, Ю. Рубін, І.Н. Айнутдінова, М.Г. Євдокімова, Л.І. Міронова та ін. Про необхідність грамотного підходу до розробки і впровадження електронних курсів в процес навчання іноземних мов 3 метою формування позитивного відношення до даного виду навчання у студентів висловлюються в своїх працях британський методист Д. Марш, західні вчені С. Чейпелл, П. Ругвен-Стюарт, Д. Хансон, А. Браун і багато інших.

Формулювання цілей статті. Визначити сутність технології Blended Learning та обгрунтувати перспективність ії застосування під час викладання іноземних мов у немовних закладах освіти.

Основна частина. Вперше основні принципи змішаного навчання застосовувалися ще в шістдесятих роках $\mathrm{XX}$ століття в корпоративній та вищій освіті, але сам термін був вперше використаний в 1999 році, коли американський Інтерактивний Навчальний Центр розпочав випуск програмного забезпечення, призначеного для викладання через Інтернет. На відміну від багатьох інших педагогічних технологій, змішане навчання не має конкретного авторства i складалося багато в чому спонтанно, в результаті численних спроб змінити існуючі методи і принципи навчання. Така спонтанність i багатофакторність розвитку змішаного навчання викликає складності при аналізі даної технології, які починаються зі спроб сформулювати чітке визначення. Трактування термінузначно різнилися, поки в 2006 році не вийшла книга авторів Бонк і Грем, де з'явилося перше достатньо чітке визначення змішаного навчання, що відображає його основні особливості: “Змішане навчання - це система навчання, заснована на поєднанні очного (віч-на-віч) та навчання комп’ютерними засобами" [1].

Інститут Клейтона Крістенсена (Christensen) дає ще більш вузьке і конкретне визначення, де змішане навчання - це освітній підхід, який поєднує навчання з участю вчителя (віч-на-віч) з он-лайн навчанням і передбачає елементи самостійного контролю студентом шляху, часу, місця і темпу навчання, а також інтеграцію досвіду навчання 3 викладачем й он-лайн [2].

У доповіді "Визначення змішаного навчання" воно визначається, як діапазон можливостей, представлених шляхом об'єднання Інтернету та електронних засобів масової інформації, з формами, які вимагають фізичної присутності в класі викладача і учнів [3].

Слід, однак відзначити, що з розширенням різноманітності комп’ютерних технологій, появою понять “електронне навчання" (2015) (як поняття більш широкого, ніж он-лайн навчання) $\mathrm{i}$ “мобільне навчання”, а також з використанням в моделях змішаного навчання цифрових ресурсів в режимі офлайн, слід сформулювати визначення дещо інакше. Змішане навчання - це освітня технологія, в якій поєднуються очне й електронне навчання 3 можливістю самостійного вибору учнем часу, місця, темпу і траєкторії навчання.

Студент відвідує аудиторні заняття, але при цьому широко використовуються і так звані Computer-Mediated Activities, тобто медіатором освітньої активності виступають комп’ютер, онлайн режим, мобільні девайси й спеціальні навчальні програми / платформи / ресурси.

Найчастіше вживаються такі синонімічні назви даного підходу до навчання іноземним мовам, як Hybrid Learning (гібридне навчання), TechnologyMediated Instruction (навчання за допомогою технологій), Web-Enhanced Instruction (навчання, що підкріплюється можливостями Інтернету) i Mixed-Model Instruction (навчання в змішаному режимі).

Концепція Blended Learning включає три складові: дистанційне навчання (Distance Learning), навчання в аудиторії (Face-To-Face Learning) i навчання через Інтернет (Online Learning).

Виокремлюють шість моделей змішаного навчання:

Face-to-Face Driver (модель, спрямована на підкріплення традиційного очного навчання). Викладач на занятті в аудиторії дає основний обсяг навчального матеріалу, використовуючи технології он-лайн навчання в якості допоміжного. Ця модель часто охоплює аудиторну і лабораторну роботу на комп’ютерах. 


\section{ЗАСТОСУВАННЯ МОДЕЛІ ВLЕNDED LEARNING ПІДЧАС ВИКЛАДАННЯ КУРСУ "ІНОЗЕМНАМОВАЗАПРОФЕСЙНИМСПРЯМУВАННЯМ"}

Rotation Model (ротаційна модель). Відбувається чергування традиційного очного аудиторного навчання і самостійного он-лайн навчання в індивідуальному режимі (наприклад, через Інтернет за планом посилань, складеним викладачем; на спеціальному сайті).

Online Lab (он-лайн лабораторія). Он-лайн платформа використовується для проведення всього курсу навчання на аудиторних заняттях. Таке навчання проходить під керівництвом i контролем тьютора. Дана програма може поєднуватися з традиційною в рамках звичайного розкладу.

Flex Model (гнучка модель). Більша частина навчальної програми освоюється в умовах електронного навчання. Викладач супроводжує кожного студента дистанційно, для відпрацювання тем, складних в розумінні, він організовує очні консультації 3 невеликими групами або індивідуально.

Self-Blend Model (модель “Змішай сам”). Студент самостійно вирішує, які курси йому необхідно доповнити он-лайн заняттями.

Online Driver Model (переважно дистанційне навчання). Дана модель передбачає навчання на відстані, тобто через певну платформу і студент контактує з викладачем он-лайн [4].

Окремо ці моделі використовуються рідко. Зазвичай їх комбінують. Наприклад, Face-to-Face 3 Flex: крім відвідування занять, студенти самостійно займаються он-лайн, а незрозумілі моменти обговорюють потім 3 викладачем.

Таким чином, змішане навчання - це система навчання/викладання, яка поєднує в собі найбільш ефективні аспекти й переваги викладання в класній кімнаті та інтерактивного або дистанційного навчання; складається з різних частин, які функціонують в постійному взаємозв'язку один з одним, утворюючи деяке

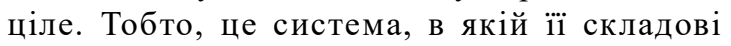
гармонійно взаємодіють, за умови, що усі ці компоненти грамотно методично організовані.

Технологія Blended Learning широко використовується в західних країнах, і існує статистика, згідно якої працедавці з великим бажанням беруть на роботу випускників он-лайн або змішаних програм, оскільки вони не лише мають навички роботи 3 новими комп'ютерними технологіями, але і здатні самостійно працювати й навчатися [5].

Особливо актуальним, на нашу думку, $є$ застосування даної технології для реалізації курсу “Іноземна мова за професійним спрямуванням" в немовному закладі освіти. Відповідна дисципліна $\epsilon$ сьогодні однією 3 найбільш затребуваних зважаючи на величезну освітнього потенціалу та комунікативної значущості.

Десятиліттями вчителя використовували магнітофони, лінгафонні класи, відео, і досі вони служать надійною опорою викладачеві під час заняття в аудиторії. 3 появою комп'ютерів можливості навчання значно розширилися комп'ютерне тестування, використання відеокурсів і інших опцій комп'ютера. 3 появою Інтернету інформаційно-комунікативні технології (ІКТ) ще більше розширили можливості викладачів - доступ до автентичних іншомовних текстів, можливість спілкування он-лайн з носіями мови, використання навчальних програм на мові та багато що інше.

Використання технології змішаного навчання іншомовного спілкування обумовлено дефіцитом аудиторного часу, збільшенням кількості годин, що відводяться на самостійну роботу студентів, але, перш за все, зміною ролей студента і викладача в навчальному процесі. У традиційній освітній системі викладач передавав студенту знання згідно з програмою, тобто виступав в ролі інструктора. В даний час все частіше говорять про отримання студентами нових знань шляхом взаємодії інформації, що надходить ззовні, з уже наявними у них знаннями. Дійсно, таке трактування навчання передбачає значний ступінь автономії студента при вивченні дисципліни, а також проявлення здатності відповідати за процес навчання.

Викладання іноземної мови у вишах здійснюється за традиційною схемою. Основними джерелами інформації на занятті є лекційний матеріал та підручники, під час практичного зайняття студенти удосконалюють навички читання, перекладу, усної мови, використовуючи відео та аудіо записи. Викладач здійснює контроль самостійно або використовуючи комп'ютерні тестові завдання.

Технологія Blended learning бере корисне 3 традиційної моделі та вдосконалює її можливості.

- Лекційне зайняття. Студентам доступний повний матеріал лекцій зі слайдами в СДО і вони легко можуть використовувати їх для самостійного вивчення.

- Практичне зайняття. Викладач може об’єднати практичні заняття з лекціями, під час таких занять будуть обговорюватися найцікавіші та найважливіші теми курсу і відпрацьовуватися практичні навички.

- Навчальні матеріали. Вони є як і в друкованому, такі в електронному форматі, викладач складає перелік джерел, де вказана вся необхідна основна та додаткова література, 


\section{ЗАСТОСУВАННЯ МОДЕЛІ ВLЕNDЕD LEARNING ПІДЧАС ВИКЛАДАННЯ КУРСУ "ІНОЗЕМНАМОВАЗА ПРОФЕСІЙНИМ СПРЯМУВАННЯМ"}

посилання Інтернету для того, щоб студент міг користуватися при потребі.

- Он-лайн спілкування. Цей вид взаємодії студента й викладача, що взятий $з$ дистанційної форми навчання. Існують різні можливості, які дозволяють студентам і викладачеві спілкуватися і працювати разом: форум, скайп, чат тощо.

- Індивідуальні й групові проекти. Даний спосіб навчання допомагає розвивати навички пошуку й аналізу інформації, знайденої в Інтернеті, навички праці в гурті, уміння правильно розподіляти обов’ язки та відповідати за свої рішення.

- Віртуальна класна кімната. Цей інструмент дає змогу студентам використовувати різні засоби Інтернет - комунікацій, знаходячись на відстані, що дає студенту певну долю свободи під час вивчення курсу.

- Аудіо і відеолекції. Ці елементи змішаного навчання роблять процес навчання простим $\mathrm{i}$ більше насиченим [6].

Висновки. Можна з упевненістю стверджувати, що змішане навчання - необхідна освітня технологія, яка робить освітній процес гнучким (оскільки забезпечується незалежність навчального курсу від часу, тривалості занять), модульним (планується індивідуальна освітня траєкторія відповідно до потреб), доступним (географічне положення студента не впливає на процес навчання), мобільним (завдяки налагодженому зв'язку між студентом і викладачем).

Варто зазначити, що змішане навчання охоплює одночасно велику кількість студентів, використовуються різні дидактичні підходи в навчанні, існує можливість застосовувати в процесі навчання такі допоміжні елементи, як відео та аудіоролики, графіки та схеми, посилання на Інтернет-ресурси, спілкування на форумах $\mathrm{i}$ обмін інформацією.

В змішаному навчанні $\epsilon$ все необхідне для спілкування іноземною мовою: жива комунікація, перегляд відеороликів і аудіювання, вивчення нових слів під час ділової гри тощо. Blended learning бере найкраще з он-лайн і оффлайн форматів, уникаючи всіх недоліків. За допомогою сучасних технологій людина занурюється в мовне середовище. Це робить навчання більш комфортним і ефективним.

\section{ЛIТЕРАТУРА}

1. Bonk C. J., Graham, C. R. Handbook of blended learning: Global Perspectives, local designs [Книга] / C. J. Bonk, C. R. Graham.- San Francisco, CA: Pfeiffer Publishing, 2006.

2. Christensen Institute [Electronic resource]: [website]. - Electronic text data. - 2017. - Mode of access: https://www.christenseninstitute.org/blended-learning/. Title from the screen.
3. Friesen N. Report: Defining Blended Learning [Electronic resource] / Norm Friesen - Electronic text data. - 2012. - Mode of access: http://learningspaces.org/ papers/Defining_Blended_Learning_NF.pdf. - Title from the screen.

4. Гарбуза Т.В. Змішане навчання професійного іншомовного спілкування студентів немовних спеціальностей / Т.В. Гарбуза // Вища освіта:удосконалення якості підготовки фахівців: матеріали Міжнародної наукової Інтернет конференції, 26-27 квітня 2018 р., м. Київ. -Київ: Альфа-ПІК, 2018. C. $165-168$.

5. Rossett A., Frazee R. Blended learning opportunities [Electronic resource] / Allison Rossett, Rebecca Vaughan Frazee. - Electronic text data. -2015. - Mode of access: https:/ /www.researchgate.net/profile/Rebecca Frazee/publication/ 228669485 Blended Learning Opportunities/links/ 55c1564508aed621de154484/Blended-LearningOpportunities.pdf. - Title from the screen.

6. Щербакова О. Л. Змішане навчання як форма організації навчального процесу з іноземної мови у ВНЗ [Електронний ресурс] / О. Л. Щербакова, Ж. В. Ніколаєва // Молодий вчений. - 2017. - №4. - С. 69-73. - Режим доступу: http://molodyvcheny.in.ua/files/ journal/2017/4.1/18.pdf.

\section{REFERENCES}

1. Bonk, C. J., \& Graham, C. R. (2006). The handbook of blended learning environments: Global perspectives, local designs. San Francisco: Jossey-Bass - Pfeiffer. [in English].

2. Clayton Christensen Institute (2018). Blended learning. Retrieved from: $h$ ttps://www.christenseninstitute.org/ blended-learning/. [in English].

3. Friesen, N. (August 2012). Report: Defining blended learning. Retrieved from: http://learningspaces.org/ papers/Defining_Blended_Learning_NF.pdf. [in English].

4. Harbuza, T.V. (2018). Zmishane navchannia profesiinoho inshomovnoho spilkuvannia studentiv nemovnykh spetsialnostei [Blended learning of professional foreign language communication of students of non-language specialties]. Higher Education: Improving the Quality of Specialist Training. Proceedings of the International Internet Conference. Kyiv, Ukraine: Alfa-PIK. pp. 165-168. [in Ukrainian].

5. Rossett, Allison, \& Frazee, Rebecca Vaughan (2006). Blended Learning Opportunities. AMA Special Report. Retrieved from: https://www.researchgate.net/profile/ R e b e c c a Fraze e/publicat i o n 228669485 _Blended_Learning_Opportunities/links/ 55c1564508aed621de154484/Blended-LearningOpportunities.pdf. [in English].

6. Shcherbakova, O. L. \& Nikolaieva, Zh. V. (2017). Zmishane navchannya yak forma organizaciyi navchalnogo procesu z inozemnoyi movy $u$ VNZ [Blended learning as a form of organization of a learning process in a foreign language at a university]. Young Scientist. Series: Pedagogics, no.4, pp.69

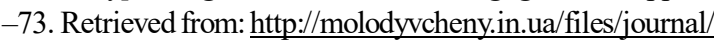
2017/4.1/18.pdf. [in Ukrainian].

Стаття надійшла до редакції 14.11.2018 